\title{
Monitoring on Bird Communities Present in a Regional Nature Reserve in the Municipality of Rome
}

Alessio Rivola* and Alessandro Ammann

Associazione Culturale Nereide Via di Torre Gaia 52 00133, Rome, Italy

*Corresponding author: Alessio Rivola, Associazione Culturale Nereide Via di Torre Gaia 52 00133, Rome, Italy, Tel: 0670491691; E-mail: alessiorivola@hotmail.com

Rec date: April 04, 2014; Acc date: June 5, 2014; Pub date: June 13, 2014

Copyright: @ 2014 Rivola et al., This is an open-access article distributed under the terms of the Creative Commons Attribution License, which permits unrestricted use, distribution, and reproduction in any medium, provided the original author and source are credited.

\begin{abstract}
The Marcigliana Regional Natural Reserve was established in 1997 in the northern area of Rome district. It is 4,729 hectares wide and it is managed by the Regional Istitutio "Roma Natura" and the importance of the area, object of our study, is demonstrated by the specific richness and mainly by the percentage of Passerine/Non Passerine that show the great importance of mosaic agriculture areas for birds' conservation.
\end{abstract}

Keywords: Bird communities; Marcigliana Regional Natural Reserve; Municipality of Rome

\section{Study Area}

The Marcigliana Regional Natural Reserve was established in 1997 in the northern area of Rome district. It is 4,729 hectares wide and it is managed by the Regional Istitutio "Roma Natura" [1].

Its environment is mainly constituted by low-high hills, which are cultivated with wheat, corn and Mediago sativa, by areas which are destined to grazing and finally by valleys all covered by oak-woods (Quercus spp.), often mixed white mapels (Acer campestris and elms (Ulmus campestris) $[2,3]$.

There are several channels e some ponds with Igrophilic vegetation, among which we can find of poplar (Populus spp.) and willows (Salix spp.).

Only $2 \%$ of entire area is urbanized.

All though this is an area of great environmental importance, it has never been studied until this study.

\section{Material and Methods}

The authors have carried out the researches between November 2012 and august 2013, with two trips per month, and from January 2011, with less frequent trips are also carried three night trips [4-7].

This study is at preliminary step and is going to last at least for one more year.

Surveys with the Regional reserve guard have been also carried out to get more information about the presence of some species $[8,9]$.

On the basis of the dates of examination and of the behaviour of the single species, we tried to attribute these species with the following Phenology:

- $\mathrm{W}$ (wintering)=Species observed in winter time o during winter birds census (15 December. 15 January)

- B (breeding) certainly=See the nest, juvenile, transport breakful or transport material for the nest

- B probably=Song, territorial defense or mating

- B possible=Specie observed during the reproductive period

- $\mathrm{M}$ (migratory)=All remaining cases (reg=regular, irr=irregular)

\begin{tabular}{|l|l|l|l|l|l|}
\hline Species & Phenology & Spec List & Italian Red List & Latium Regional Red List & European Status \\
\hline Anas crecca & W, M & & EN & NA & \\
\hline Anas platyrhyncos & W, M, B cert. & & EN & NA & \\
\hline Phalacrocorax carbo & W, M & & EN & NA & NA \\
\hline Ardea cinerea & W, M & & LR & NA & \\
\hline Bubulcus ibis & W, M & & VU & NA & \\
\hline Egretta garzetta & W, M & & & & VU \\
\hline Ardeola ralloides & M irr. & & & & Vulnerable \\
\hline Pernis apivorus & M, B prob. & 3 & VU & \\
\hline Aquila pennata & M irr. & 3 & & & \\
\hline
\end{tabular}


Citation: Rivola A, Ammann A (2014) Monitoring on Bird Communities Present in a Regional Nature Reserve in the Municipality of Rome. J

Page 2 of 4

\begin{tabular}{|c|c|c|c|c|c|}
\hline Circus cyaneus & M reg. W & & Ex & & Declining \\
\hline Circus pygargos & M reg., $B$ ? & & VU & EN & \\
\hline Circus aeruginosus & M reg. & & En & & \\
\hline Milvus migrans & M reg, B prob. & 3 & VU & Vu & Vulnerable \\
\hline Accipiter nisus & W, M, B prob. & & & & \\
\hline Buteo buteo & W, M, B prob. & & & & \\
\hline Falco peregrinus & W, M, B poss. & & VU & NT & \\
\hline Falco tinnunculus & W, M, B cert. & 3 & & & Rare \\
\hline Falco naumanni & M & & & & \\
\hline Falco subbuteo & B poss. & & VU & Vu & \\
\hline Phasianus colchicus & W, M, B cert. & & & & \\
\hline Grus grus & M irr. & & & & \\
\hline Gallinula chloropus & W, M, B cert. & & & & \\
\hline Himantopus himantopus & M irr. & & LR & NA & \\
\hline Philomacus pugnax & M irr. & & & & \\
\hline Tringa ochropus & M reg. & & & & \\
\hline Gallinaga gallinago & M reg. & & & & \\
\hline Scolopax rusticola & M reg. & & & & \\
\hline Vanellus vanellus & M reg., W reg. & & & & \\
\hline Larus michaellis & W, M reg. & & & & \\
\hline Chroicocephalus ridibundus & W, M & & & & \\
\hline Columba livia (feral pigeon) & $M, W, B$ & & & & \\
\hline Columba palumbus & W, M, B poss. & & & & \\
\hline Streptopelia decaocto & W, M, B prob. & & & & \\
\hline Strepropelia turtur & M, B prob. & & & & Declining \\
\hline Psittacula krameri & W, M, B cert. & & & & \\
\hline Cuculus canorus & M, B prob. & & & & \\
\hline Strix aluco & W, B cert & & & & \\
\hline Athene noctua & W, B cert & 3 & & & Declining \\
\hline Asio otus & B poss. & & & & \\
\hline Tyto alba & W, B poss. & & & & \\
\hline Apus apus & M reg, B prob. & & & & \\
\hline Alcedo atthis & W & & & & \\
\hline Upupa epops & M, B poss. & 3 & & & Declining \\
\hline Merops apiaster & M reg, B prob. & 3 & & & Depauperate \\
\hline Picus viridis & W, B prob. & 2 & LR & & Depauperate \\
\hline
\end{tabular}


Citation: Rivola A, Ammann A (2014) Monitoring on Bird Communities Present in a Regional Nature Reserve in the Municipality of Rome. J Biodivers Endanger Species 2: 131. doi:10.4172/2332-2543.1000131

Page 3 of 4

\begin{tabular}{|c|c|c|c|c|c|}
\hline Dendrocops minor & W, B poss. & & LR & & \\
\hline Dendrocops major & W, B prob. & & & & \\
\hline Galerida cristata & W, M, B prob. & 3 & $\mathrm{DD}$ & & Depauperate \\
\hline Alauda arvensis & W, M, B poss. & 3 & & & Depauperate \\
\hline Anthus pratensis & W, M & 4 & $\mathrm{NE}$ & & \\
\hline Motacilla alba & W, M, B prob. & & & & \\
\hline Motacilla flava & W & & & & \\
\hline Hirundo rustica & W, M, B cert. & 3 & & & Declining \\
\hline Cecropis daurica & M irr. & & CR & NA & \\
\hline Delichon urbicum & M, B prob. & 3 & & & \\
\hline Prunella modularis & W & & DD & & Depauperate \\
\hline Troglodytes troglodytes & W, B poss. & & & & \\
\hline Luscinia megarhyncos & M reg, B prob. & & & & \\
\hline Saxicola torquatus & W, M, B poss. & & & & \\
\hline Phoenicurus ochruros & W & & & & \\
\hline Turdus merula & W, M, B cert. & & & & \\
\hline Turdus philomelos & M reg. & & & & \\
\hline Sylvia atricapilla & W, M, B prob. & & & & \\
\hline Sylvia melanocephala & W, M, B prob. & & & & \\
\hline Sylvia cantillans & M, B poss. & & & & \\
\hline Cisticola juncidis & W, M, B prob. & & & & \\
\hline Cettia cetti & W, M, B prob. & & & & \\
\hline Hippolais polyglotta & M, B cert. & & & & \\
\hline Phylloscopus collybita & W, M, B prob. & & & & \\
\hline Phylloscopus sibilatrix & M reg. & & & & \\
\hline Regulus regulus & W & & & & \\
\hline Regulus ignicapilla & W, M, B prob. & & & & \\
\hline Parus major & W, M, B prob. & & & & \\
\hline Cyanistes caeruleus & W, M, B prob. & & & & \\
\hline Aegithalos caudatus & W, M, B prob. & & & & \\
\hline Certhia brachydactyla & W, M, B prob. & & & & \\
\hline Lanius collurio & M, B cert. & 3 & & & Depauperate \\
\hline Lanius senator & M, B poss. & 2 & & & Depauperate \\
\hline Pica pica & W, M, B cert. & & & & \\
\hline Garrulus glandarius & W, M, B prob. & & & & \\
\hline Corvus monedula & W, B prob. & & & & \\
\hline
\end{tabular}


Citation: Rivola A, Ammann A (2014) Monitoring on Bird Communities Present in a Regional Nature Reserve in the Municipality of Rome. J

Page 4 of 4

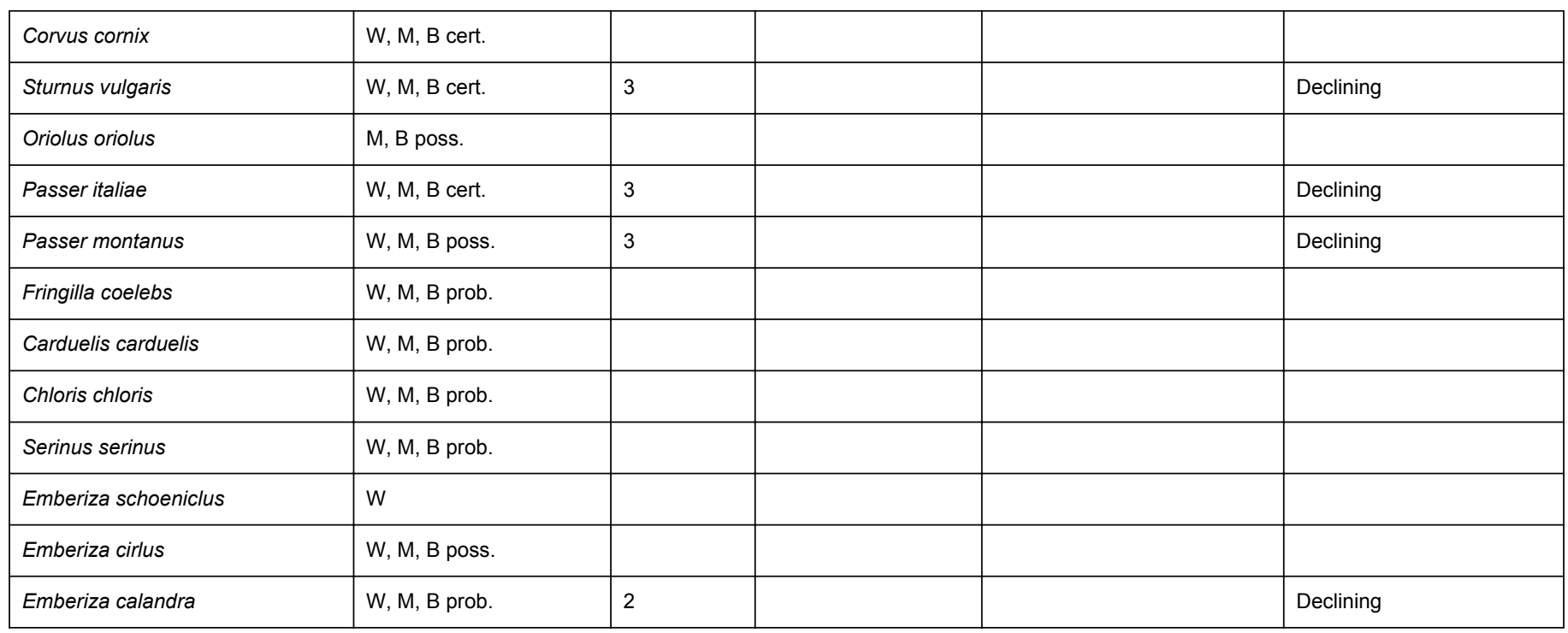

Table 1: Check List of Marcigliana Natural Reserve

\section{Results}

The species of birds that were observed in the Reserve are 97 in total, of which 52 are Non-Passerine (54\%) while 45 are Passerine (46\%) (Table 1). In the present research it was not included Calandrella brachydactyla, which was spotted during a previous research on the birds of this Reserve, but that was not reconfirmed in the present study.

There are 19 species (18.7\%) which are included in the European SPEC 1-3 lists; 19 species (18.7\%) are included in the Italian Red List and 14 species (13.1\%) are instead included in the Regional Red List of Latium. Particularly interesting is the high number of species of raptors spotted (12), 7 of which breeding, and 5 wintering. Among the breeding species the most important is the Circus pygargos, which is at risk of extinction of great importance is also the density of Strigiformes, with at least 14 territories of Atehena noctua, 9 of Strix aluco al and at least one each of Tyto alba and Asio otus.

Despite being the right habitat for Caprimulgus europaeus and Otus scops, these species have never been spotted during previous researches.

It would be interesting to do some more researches on the following species:

Circus pygargus, first spotted in 2012. During our study, it was observed 5 times between May and August. It would be necessary to confirm the breeding of this species in this Reserve, for the conversation of this species in Latium.

Milvus migrans, regularly observed with many individuals and so there might be pairs breeding in this Reserve.

Lanius minor, of which there are 5 pairs in the Reserve.

Lanius senator, of which there is one pair in the Reserve (Carlo Catoni, personal communication).

\section{Conclusion}

The importance of the area, object of our study, is demonstrated by the specific richness and mainly by the percentage of Passerine/Non Passerine that show the great importance of mosaic agriculture areas for birds' conservation.

\section{Acknowledgement}

The Reserve staff and Managing Directors and everyone who contributed to our study with additional data.

\section{Summary}

Birds of the Regional Reserve of the Marcigliana, Rome, Central Italy.

\section{References}

1. Birdlife International (2004) Birds in the European Union: a Status assessment. Wageningen The Netherlands Birdlife International

2. Brunelli M, Corbi F, Sarrocco S, Sorace A (a cura di) (2009) L'avifauna acquatica svernante nelle zone umide del Lazio. Edizioni ARP (Agenzia Regionale Parchi), Roma-Edizioni Belvedere, Latina: 176.

3. Brunelli M, Sarrocco S, Corbi F, Sorace A, Boano A ( 2011) Nuovo Atlante degli Uccelli Nidificanti nel Lazio. Edizioni ARP (Agenzia Regionale Parchi), Roma: 464

4. Boano et alii (Ed) (1995) Atlante degli uccelli nidificanti nel Lazio. Alula, II (1-2): 1-224.

5. Cignini B., Zapparoli M. (a cura di) (1996) Atlante degli uccelli nidificanti a Roma.

6. Fratelli Palombi Editorial.

7. Peronace V, Cecere JC, Gustin M, Rondonini C (2012) Lista Rossa 2011 degli Uccelli Nidificanti in Italia. Avocetta: 36.

8. Sarrocco $S$ et al (2002) L'avifauna delle aree naturali protette del Comune di Roma gestite

9. dall'Ente RomaNatura, Alula, vol. IX (1-2)-2002: 3-31. 